\title{
Bronchoalveolar lavage cell analysis in patients with human immunodeficiency virus related diseases
}

\author{
VICENTE PLAZA, PATRICIO JIMÉNEZ, ANTONI XAUBET, CESAR PICADO, \\ ANTONI TORRES, CARLES AGUSTÍ, ALBERT AGUSTÍ-VIDAL \\ From the Servicio de Neumologí, Hospital Clinic, Barcelona, Spain
}

\begin{abstract}
The value of differential cell counts in bronchoalveolar lavage fluid in patients who were serologically positive for the human immunodeficiency virus (HIV) was studied in 30 patients with classified into four groups according to the severity of illness: (1) seven subjects with the AIDS related complex without clinical or radiological evidence of pulmonary infection; (2) eight patients with the AIDS related complex and pulmonary tuberculosis; (3) eight patients with AIDS and Pneumocystis carinii pneumonia; and (4) seven patients with AIDS, Pneumocystis carinii pneumonia, and severe respiratory failure. All four groups had a similar percentage of lymphocytes, significantly higher than that of a control group of 15 healthy volunteers. A significant increase in the percentage of neutrophils was observed in groups 2,3 , and 4 . The lavage fluid differential cell count does not therefore appear to help in the differential diagnosis of pulmonary infections in HIV positive patients. The abnormal percentage of lymphocytes observed in some patients with the AIDS related complex without clinical evidence of pulmonary infection suggests that lung injury may exist before clinical or radiological abnormalities develop. This might be related to an immunological mechanism or might be caused by an undetected subclinical infection.
\end{abstract}

\section{Introduction}

Nearly half $(41 \%)$ the patients with the acquired immunodeficiency syndrome (AIDS) develop pulmonary infiltrates due to either infection or inflammation during their illness. ${ }^{\prime}$ Bronchoalveolar lavage has been found to be useful for the diagnosis of pulmonary infections, especially for those caused by opportunist organisms. ${ }^{23}$ The role of the differential cell counts in lavage fluid, however, in the diagnosis of pulmonary complications in these patients has been addressed in only a few reports, with conflicting conclusions. Smith et al ${ }^{4}$ found a correlation between the clinical severity of illness and the percentage of neutrophils and eosinophils in bronchoalveolar lavage in patients with Pneumocystis carinii pneumonia, but White $e t a l^{5}$ found no relation between the relative proportion of cell types in lavage fluid and respiratory symptoms, radiological abnormalities, or survival from pulmonary infections caused by Pneumocystis

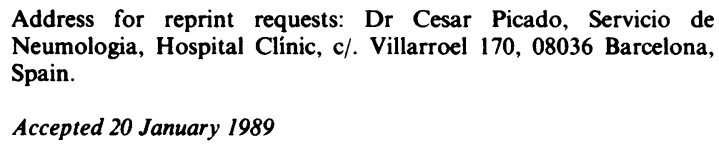

carinii, cytomegalovirus, Mycobacterium avium intracellulare, and bacteria. Changes in bronchoalveolar lavage fluid differential cell counts have also been reported in a few patients with the AIDS related complex without pulmonary disease. ${ }^{6}$

Our study was designed to investigate the clinical significance of changes in bronchoalveolar lavage fluid differential cell counts in patients with AIDS and in patients with the AIDS related complex with or without pulmonary infection. Patients were classified in different groups on the basis of strict criteria.

\section{Methods}

\section{PATIENTS}

From September 1985 to April 1987 we studied 30 HIV positive patients ( 28 of them male). Twenty one were heroin addicts, nine were homosexual, and one had haemophilia. Patients were classified into four groups on the basis of microbiological studies, as follows: Group 1-patients with the AIDS related complex, without clinical symptoms or radiological abnormalities to suggest respiratory infection; these patients underwent fibreoptic bronchoscopy because they had pyrexia of unknown origin. Group 2- 
patients with the AIDS related complex and pulmonary tuberculosis. Group 3-patients with AIDS and Pneumocystis carinii pneumonia. Group 4-patients with AIDS and Pneumocystis carinii pneumonia who developed severe respiratory failure (arterial oxygen tension $6.5 \mathrm{kPa}$ breathing $\geqslant 35 \%$ oxygen).

The bronchoalveolar lavage fluid differential cell counts from 15 healthy volunteers ${ }^{7}$ were used as control data. AIDS was diagnosed in accordance with the criteria defined by the Centers for Disease Control of Atlanta, Georgia. ${ }^{8}$

\section{FIBREOPTIC BRONCHOSCOPY AND LAVAGE}

Fibreoptic bronchoscopy was performed with an Olympus BF-B3 bronchoscope (Olympus Corporation of America, New York), one instrument being used exclusively for all HIV positive patients. Firstly, a telescoping plugged brush catheter (Medi Tech BFW $10 / 70 / 90$ ) was used to obtain uncontaminated bronchial secretions, as described by Wimberley et al. ${ }^{9}$ From this material several smears were prepared for Gram and Ziehl-Nielsen staining and cultures were established for aerobic and anaerobic bacteria and fungi with quantitative analysis of colony forming units. A colony count of $10^{3}$ or more was considered to indicate infection. ${ }^{10}$ Bronchoalveolar lavage was then performed from the middle lobe or lingula in the patients with diffuse radiological infiltrates or a normal chest radiograph, or in the abnormal lobe when the radiological abnormality was localised. Lavage was carried out with $150 \mathrm{ml}$ of $0.9 \%$ sterile saline solution instilled in $50 \mathrm{ml}$ aliquots and aspirated by gentle manual suction.

\section{INVESTIGATIONS}

Lavage fluid was pooled and divided. Half was used for Gram, Ziehl-Nielsen, and indian ink stains and for cultures for bacteria (aerobic and anaerobic), fungi, and mycobacteria (Lowenstein). The other half was centrifuged at $1800 \mathrm{rev} / \mathrm{min}$ for 10 minutes and the cell pellet was resuspended in phosphate buffered saline. Smears were prepared by cytocentrifugation ( $500 \mathrm{rev} /$ $\mathrm{min}, 10 \mathrm{~min}$ ) (Cytospin, Shandon) and stained by the Ziehl-Nielsen, periodic acid-Schiff, Grocott methenamine silver, Perls, and May-Grünwald-Giemsa methods, and examined for the presence of acid fast bacilli, fungal hyphae and yeasts, Pneumocystis carinii and viral inclusion bodies. Differential cell counts were performed in high power fields $(\times 400)$ and 400 cells were counted. Blood cultures for bacteria (aerobic and anaerobic) and fungi were taken from all patients. In addition, sputum smears were stained by the Gram and Ziehl-Nielsen methods. Serological tests for Legionella pneumophila, Mycoplasma pneumoniae, Aspergillus fumigatus, respiratory viruses (influenzae, parainfluenzae, adenovirus, respiratory syncytial virus), cytomegalovirus, and herpesvirus were performed at the time of diagnosis. When possible, a convalescent specimen was taken two weeks later.

In the four patients from group IV who died necropsy confirmed the existence of Pneumocystis carinii pneumonia.

\section{STATISTICAL ANALYSIS}

As the distribution of variables was not normal, the non-parametric Kruskal-Wallis and Mann-Whitney tests were used for comparisons between groups. " The threshold of significance was taken as $\leqslant 0.05$.

\section{Results}

Of the 30 patients, seven were in group 1 , eight in group 2 , eight in group 3 , and seven in group 4 . The diagnosis of pulmonary infection was always made by analysis of lavage fluid and necropsy. There were no cases of bacterial pneumonia; quantitative analysis of bronchial secretions obtained by telescoping plugged catheter and blood cultures always gave negative results.

The bronchoalveolar lavage fluid differential cell counts of the control group and the four groups studied are shown in the table. All the HIV positive patients, with or without pulmonary infection, showed a lower percentage of macrophages than the control group, and all had a significantly higher percentage of lymphocytes than the control subjects. There were no significant differences in the percentages of lymphocytes between the four groups (table).

Percentages of neutrophils were significantly higher in groups 2,3 , and 4 than in the control group but did not differ between the groups (table).

Mastocytes and eosinophils were not observed in any cases.

Bronchoalveolar lavage cell analysis (mean (SD) values with 95\% confidence intervals below) in subjects with the AIDS related complex without pulmonary disease (group 1), with AIDS related complex with pulmonary tuberculosis (group 2), with AIDS and Pneumocystis carinii pneumonia (group 3), and with AIDS and Pneumocystis carinii pneumonia with severe respiratory failure (group 4)*

\begin{tabular}{|c|c|c|c|c|}
\hline Group & $n$ & $\begin{array}{l}\text { Macrophages } \\
\text { (\%) }\end{array}$ & $\begin{array}{l}\text { Lymphocytes } \\
(\%)\end{array}$ & $\begin{array}{l}\text { Neutrophils } \\
(\%)\end{array}$ \\
\hline Control & 15 & $\begin{array}{l}93.7(2.7) \\
92-95\end{array}$ & $\begin{array}{l}4.9(3.1) \\
3.2-6.6\end{array}$ & $\begin{array}{l}1.3(0.8) \\
0.9-1.8\end{array}$ \\
\hline 1 & 7 & $\begin{array}{l}79.6(17 \cdot 4)^{*} \\
63-96\end{array}$ & $\begin{array}{c}16.7(18.0)^{*} \\
0.1-33\end{array}$ & $\begin{array}{l}3.7(5 \cdot 1) \S \\
0.9-8\end{array}$ \\
\hline 2 & 8 & $\begin{array}{l}68 \cdot 1(28 \cdot 6)^{* *} \\
44-91\end{array}$ & $\begin{array}{c}17 \cdot 9(15 \cdot 1) \ddagger \\
5 \cdot 3-30\end{array}$ & $\begin{array}{l}14 \cdot 1(31 \cdot 0)^{*} \\
11 \cdot 9-40\end{array}$ \\
\hline 3 & 8 & $\begin{array}{l}60 \cdot 8(27 \cdot 4)^{* * * *} \\
38-84\end{array}$ & $\begin{array}{l}23 \cdot 1(21 \cdot 9)^{* *} \\
4 \cdot 8-41\end{array}$ & $\begin{array}{c}15 \cdot 1(23 \cdot 6)^{*} \\
4 \cdot 6-35\end{array}$ \\
\hline 4 & 7 & $\begin{array}{l}62 \cdot 6(21 \cdot 1) \dagger \\
43-82\end{array}$ & $\begin{array}{c}18 \cdot 4(9 \cdot 3) \dagger \\
9 \cdot 9-27\end{array}$ & $\begin{array}{c}18 \cdot 6(13 \cdot 8)^{*} \\
5 \cdot 8-31\end{array}$ \\
\hline
\end{tabular}

Differences from control group: ${ }^{*} \mathrm{p}<0.05 ;{ }^{* *} \mathrm{p}<0.005$; ***p $<0.0005 ;$ tp $<0.001 ; \neq p<0.01$. $\ddagger$ Difference from group 4: $p<0.05$. 


\section{Discussion}

In this study higher percentages of neutrophils and lymphocytes have been found in the bronchoalveolar lavage fluid in patients with AIDS and pulmonary infection than in a group of 15 healthy volunteers. In addition, there was a significant increase in lymphocytes in bronchoalveolar lavage in patients with the AIDS related complex without evidence of pulmonary infection. These results are similar to those reported by Young et $a^{12}$ and Venet et al, ${ }^{6}$ who observed an increase in lavage fluid lymphocytes in patients with AIDS without evidence of pulmonary complications.

The increase in bronchoalveolar lavage lymphocytes in the patients with AIDS contrasts with the decrease in the number of lymphocytes occasionally found in blood. Two possible explanations for this finding are, firstly, pulmonary sequestration of peripheral lymphocytes and, secondly, local proliferation of lymphocytes. The results of our study show that lymphocytosis of lavage fluid is already present at an early stage of the disease, before there is any clinical expression of disease. This observation may indicate the presence of an inflammatory or immunological alteration (or both) within the pulmonary parenchyma, possibly associated with HIV infection, or possibly related to pulmonary infections that have not been diagnosed with the usual techniques of investigation.

Smith et al $^{4}$ studied 19 patients with AIDS and Pneumocystis carinii pneumonia, and observed that the patients with increased neutrophils and eosinophils in lavage fluid had a worse clinical course than those with normal concentrations of neutrophils and eosinophils. The presence of concomitant infection was not clearly excluded in these patients. Our results are different. Although we observed an increase in neutrophil numbers in all the patients with pulmonary infection, whatever the aetiology (groups 2, 3, and 4), we found no correlation between the degree of neutrophilia in the lavage fluid and disease severity. This lack of concordance may be due to one or more of several factors: (1) patients studied at different stages of the disease; (2) inclusion of patients with bacterial infections in Smith's series (this would account for an increase in bronchoalveolar lavage neutrophils in these patients $\left.{ }^{13}\right) ;(3)$ the small size of the groups being studied; (4) differences in the patients studied with respect to the factors predisposing to infection with the human immunodeficiency virus (drug abuse versus homosexuality, etc) - in our study there were more drug abusers than homosexual patients. A direct effect of drugs and other substances (talc) on lung parenchyma and bronchoalveolar lavage fluid differential cell counts cannot be excluded.

In summary, our results show that patients with the AIDS related complex show abnormalities in the differential cell count in the lavage fluid that may be explained either by immunological reactions or by a subclinical infection not diagnosed by standard techniques. The cell count does not, however, appear to be useful in the diagnostic and prognostic evaluation of pulmonary infections in these patients.

We are indebted to M Carrión for her technical help in performing lavage fluid cell analysis. PJ was a postdoctored fellow from the Universidad Austral, Chile. The work was supported by a grant $(0770 / 84)$ from the Comisión Asesora de Investigación Cientifica y Técnica.

\section{References}

1 Murray JF, Felton CP, Garay SM, Gottlieb MS, Hopewell PC, Stover DE. Pulmonary complications of the acquired immunodeficiency syndrome: report of National Heart, Lung, and Blood Institute workshop. $N$ Engl J Med 1984;310:1682-8.

2 Xaubet A, Torres A, Ramirez J, et al. Diagnostico delos infiltrados pulmonares en los pacientes con sindrome de inmunodeficiencia adquirida. Med Clin (Barcelona) 1987;88:311-4.

3 Stover DE, Zaman MB, Hadju SI, Lange M, Golg J, Armstrong D. Bronchoalveolar lavage in the diagnosis of diffuse pulmonary infiltrates in the immunosuppressed host. Ann Intern Med 1984;101:1-7.

4 Smith RL, El Sadr W, Lewis ML. Correlation of bronchoalveolar lavage cell populations with clinical severity of Pneumocystis carinii. Chest 1988;92:60-4.

5 White DA, Gellene RA, Gupta S, Cunninghan-Rundles C, Stover DE. Pulmonary cell populations in the immunosuppressed patient. Chest 1985;88:352-9.

6 Venet A, Sandron D, Clavel F, et al. Bronchoalveolar lavage in acquired immunodeficiency syndrome [abstract]. In: Proceedings of conference on bronchoalveolar lavage. Columbia, Maryland: Pulmonary Branch, National Heart, Lung, and Blood Institute, 1984:99.

7 Xaubet A, Rodriguez R, Bombí JA, Marin A, Roca J, Agustí Vidal A. Correlation of bronchoalveolar lavage and clinical and functional findings in asbestosis. Am Rev Respir Dis 1986;133:848-54.

8 Centers for Disease Control, Department of Health and Human Services. Revision of the case definition of acquired immunodeficiency syndrome for national reporting. Ann Intern Med 1985;163:402-3.

9 Wimberley NW, Bass JB, Boyd BW, Kirkpatrick MB, Serio RA, Pollock HM. Use of a bronchoscopic protected catheter brush for the diagnosis of pulmonary infections. Chest 1982;81:556-62.

10 Torres A, Puig J, Rodriguez R, Jimenez MT, Pumarola A, Agustí Vidal A. Telescoping plugged catheter by Metras sonda: an alternative tool for diagnosing bacterial pneumonia in mechanically ventilated patients. Am Rev Respir Dis 1988;138:117-20.

11 Norusis MJ. SPSS/PC+ for the IBM PC/XT. Chicago: SPSS Inc, 1986.

12 Young KR, Rankin JD, Naegel GP, Paul ES, Reynolds HY. Bronchoalveolar lavage cells and proteins in patients with the acquired immunodeficiency syndrome. Ann Intern Med 1985;103:522-33.

13 Thorpe JE, Baughman RP, Frame PT, Wesseler TA, Staneck JL. Bronchoalveolar lavage for diagnosing acute bacterial pneumonia. J Infect Dis 1987;155: $855-61$. 